\title{
Theoretical Basis of Studying the Information Space
}

\author{
Selishcheva T.A. \\ The St. Petersburg State University of Economics, \\ Saint Petersburg, Russia, \\ selishcheva@list.ru \\ Dyatlov S.A. \\ The St. Petersburg State University of Economics, \\ Saint Petersburg, Russia, \\ oetdsa@yandex.ru
}

\author{
Asalhanova S.A. \\ The St. Petersburg State University of Economics, \\ Saint Petersburg, Russia, \\ asa_1@list.ru \\ Romanova T.G. \\ The Buryat State Academy of Agriculture, \\ Ulan-Ude, Russia, \\ tamara.rom@mail.ru
}

\author{
Potapenko A.V. \\ Russian Customs Academy Saint-Petersburg \\ Branch named after V.B. Bobkova, \\ Saint Petersburg, Russia
}

\begin{abstract}
The article is devoted to the study of the development of the digital economy and the formation of a single national information space in Russia. The article discusses approaches to defining the concept and structure of the information space. The problems of heterogeneity of the information space in the form of a digital divide are touched upon.
\end{abstract}

Keywords-digital economy, information space, information society, digital divide

\section{INTRODUCTION}

Information and communication technologies (ICT) and information are today an important resource for transforming the world economy and economic development models. The number of Internet users in the world in 2020 reached 4.54 billion, mobile phone users - 5.19 billion [1]. Global Internet Protocol (IP) -based traffic, which gives a rough idea of the scale of data flows, has grown from about 100 gigabytes (GB) per day in 1992 to over 45,000 GB per second in 2017 [2]. The classic of the theory of post-industrial economics D. Bell in his writings noted the enormous importance of information for modern society. He characterized information as the basis of power, and access to information as a condition of freedom [3, p. 330]. Information in the modern economy is becoming a product of mass consumption. The volumes of reception, storage, transmission and consumption of information are growing rapidly along with the development of information and communication technologies and information infrastructure. According to expert data, up to $70 \%$ of world
GDP depends on one degree or another of information circulating in information systems.

The development of ICT has led to the emergence of information production, and information has become the result of the production process. Creation, transmission, storage and processing of information are gradually becoming the fundamental sources of growth in labor productivity, the emergence of new methods of competition, changes in the structure of the economy. The information space is being formed at the national and global levels.

\section{MATERIALS AND METHODS}

There are various approaches to defining the information space within the framework of various scientific schools and research areas. For example, the complex research method allows to determine two main approaches of the information space definition. First, the information space is treated as an intangible environment or space of information or information objects. Secondly, it is viewed as a set of information resources, technologies, information infrastructure. Within the framework of the first scientific approach, scientists I.A. Lazarev and G.S. Khizha prove that the information space "is the result of the information display of the material space," [4, p.22]. Within the framework of the first scientific approach, the information space definition is also given as a space in which "information is created, moved and consumed" [5]. This definition reflects such a function of the information space as information exchange and interaction, which results in expansion and enrichment of the information base of society, renewal of the society itself [6]. 
Within the framework of the second scientific approach, the information space is defined as the space formed by information resources, interaction technologies and information infrastructure, which is formed in the process of informatization of the economy and society [7, p. 4]. Girich V.L. and Chuprina V.N. defined the information space as "a set of information resources and infrastructures that make up state and interstate computer networks, telecommunication systems and public networks, other cross-border information transmission channels" [8, p. 141]. In the definitions of this scientific approach, the technical component prevails and a rather narrow interpretation of the information space is given. However, the information space is not only a set of information and communication technologies, information systems and infrastructure. Consequently, the definitions within the framework of the second scientific approach do not give a comprehensive, interdisciplinary description of the category of "information space".

In our opinion, the most complete definition of the essence of the information space can be given from the standpoint of an interdisciplinary approach. We support the point of view of V.Y. Tsvetkov. that the information space has a dual nature. On the one hand, it is an information model. On the other hand, it serves as a tool for influencing the surrounding world at the local and global levels [9, p. 207]. Katkova M.V. also gives an interdisciplinary definition of the information space, which combines economic, legal, management and information approaches [10]. Information space is a multifaceted phenomenon, the formation of which is based on information in the form of knowledge, theories, models, systems [11].

\section{RESULTS}

The authors of define the information space as a complex of relations arising in the process of information interaction of subjects, including the production, storage, exchange and consumption of information based on the use of information and communication technologies.

In the structure of the information space, the following elements are distinguished: information resources and information and organizational infrastructure that provides storage, transmission and reception of information by consumers. Information resources contain databases, information, knowledge, recorded in a certain form and on certain media. The information and organizational infrastructure includes not only ICT and information systems, but also the organizational and regulatory structure of information interaction between subjects. This structure operates on the basis of a system of normative legal acts regulating the information sphere. The information space is characterized by heterogeneity. Information resources, information networks and information infrastructure are unevenly distributed within the global and national information space. As a rule, a high density of information space, and, accordingly, a concentration of information resources, is observed in regions with a high level of informatization and a developed information infrastructure. The heterogeneity of the information space manifests itself in the form of information (digital) inequality (or digital divide). The digital divide represents unequal consumer access to information resources, exacerbating economic, social and cultural inequalities. There is no absolutely homogeneous information space, but reducing the digital divide increases the efficiency of both information and economic space.

\section{DISCUSSION}

It seems that the interdisciplinary approach is the most promising for studying the essence of the information space. Within the framework of an interdisciplinary approach, the information space is a historically defined set of relations arising as a result of information interaction of subjects in the process of production, storage, exchange and consumption of information based on the use of ICT and information technology infrastructure.

This approach made it possible to identify the qualitative characteristics of the information space: virtualization; density (the level of penetration of the Internet and cellular communications, the level of development of electronic services, the level of development of the information market, etc.); connectivity (level of development of information infrastructure, quality of the Internet, quality of cellular communications); the degree of homogeneity (differentiation); openness.

The density of the information space depends on the level of implementation of broadband access to the Internet. The penetration of $4 \mathrm{G}$ cellular communication is growing and $5 \mathrm{G}$ technologies are developing, which provide high-speed mobile Internet access. This contributes to the development of the market for information services, electronic commerce and an increase in the density of the information space. At the end of $2019,93 \%$ of the world's population was able to access the Internet through a $3 \mathrm{G}$ network or higher. The initial adoption of $5 \mathrm{G}$ networks in developed countries is expected to exacerbate the existing digital divide, as developing countries are likely to take longer to implement $5 \mathrm{G}$ networks [12]. Mobile broadband subscriptions reached 83\% in 2019. In developing countries, mobile broadband subscriptions reached 75.2 per 100 inhabitants in 2019. In least developed countries, penetration rates rose from near zero in 2007 to 33.1 per 100 people in 2019. In Russia, the number of broadband Internet subscribers per 100 people of the population on mobile access in 2019 grew by $10 \%$ and amounted to 96.4. Dynamics of the number of mobile broadband Internet subscribers per 100 people is shown in Fig. $1[13,14,12,1,15]$. Fixed broadband Internet access in 2019 is 22.16 per 100 people [13]. World Bank studies show that a $10 \%$ increase in broadband Internet penetration increases a country's GDP by 1.2-1.4 percentage points [14].

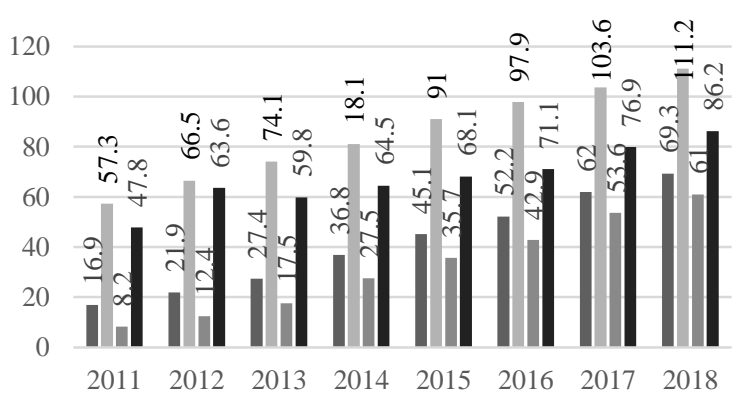

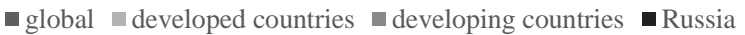

Fig.1. Dynamics of the number of mobile broadband subscribers per 100 people 
The development of ICT erases the territorial boundaries of the national information space, ensuring its openness. It actively interacts with the information spaces of other countries and contributes to the formation of a global information space. The national information space is closely interconnected with the economic space and affects the efficiency of its functioning. Information interaction of economic entities, circulation of information resources takes place in the information space.

In turn, there is also no single approach in defining economic space. Within the framework of the regional approach, economic space is identified with a territory or defined by geographic boundaries. So, according to A.G. Granberg, the economic space is "a saturated territory containing many objects and connections between them: settlements, industrial enterprises, ..., transport and engineering networks, etc" $[16$, p. 25]. Within the framework of the resource approach, economic space is defined as "a system of relations for the use of economic resources" Within the framework of the information approach, the economic space is considered as a structured set of information flows or as a system of information exchange [17]. However, the information space does not fully correlate with the economic space and should not be identified with it.

The development of ICT leads to a powerful virtualization of both the economic and information space. Virtualization is one of the main characteristics of the information space. We support the opinion of scientists about the essence of virtualization as "any substitution of reality by its simulation". At the same time, a virtual economy is not only one in which business transactions are carried out on the Internet, but also an economy in which the sector of financial derivatives prevails over the real sector [18]. Thus, virtualization can be defined as the process of creating an information digital image (information form) of real-life objects and phenomena (material form). The growing pace of virtualization and the widespread use of the Internet contribute to the creation of a single global information space. However, the information space has a higher degree of virtuality in comparison with the economic space. Sociocultural factors also influence the specifics of the information space. The development of ICT contributes to the rapid expansion of the information space, which is more open than the national economic space.

The information space, as well as the economic space, is heterogeneous, which is manifested at the national level in the digital divide between the regions of the country, the subjects of the economy. One of the fundamental signs of the digital divide is the absence or limitation of access to ICT infrastructure. For example, in least developed countries, only one in five people uses the Internet, while in developed countries, four out of every five people have access to the Internet [2]. According to the Ministry of Digital Development, Communications and Mass Media of the Russian Federation, in 2019 in Russia from 18 thousand settlements with a population of 500 to 10 thousand people, 16 thousand had broadband Internet (BBA), and from 14 thousand settlements from 250 to 500 inhabitants, the Internet was available to 8 thousand [19]. At the same time, the information inequality is based on the regions socioeconomic inequality. The indicators of the socio-economic development of the leading regions and the level of the
Digital Russia index are interdependent: the leading regions in the socio-economic development are the leaders of the named index. The huge differentiation of regions in terms of socio-economic development is evidenced, for example, by the regional scope of variation in the volume of GRP per capita, which amounted to: in 1998 - 18.7 times (on the edges of the series - Tyumen region and the Republic of Ingushetia), in 2008 - 24.3 times (the same regions), in 2017 - 39.9 times (Yamalo-Nenets Autonomous District and Ingushetia). The gap in investment per capita (between the maximum and minimum value) by regions was: in 2000 - 180 times (Yamalo-Nenets Autonomous District and the Republic of Tyva), in 2018 - 70 times (Nenets Autonomous Okrug and Ivanovo Oblast) [20].

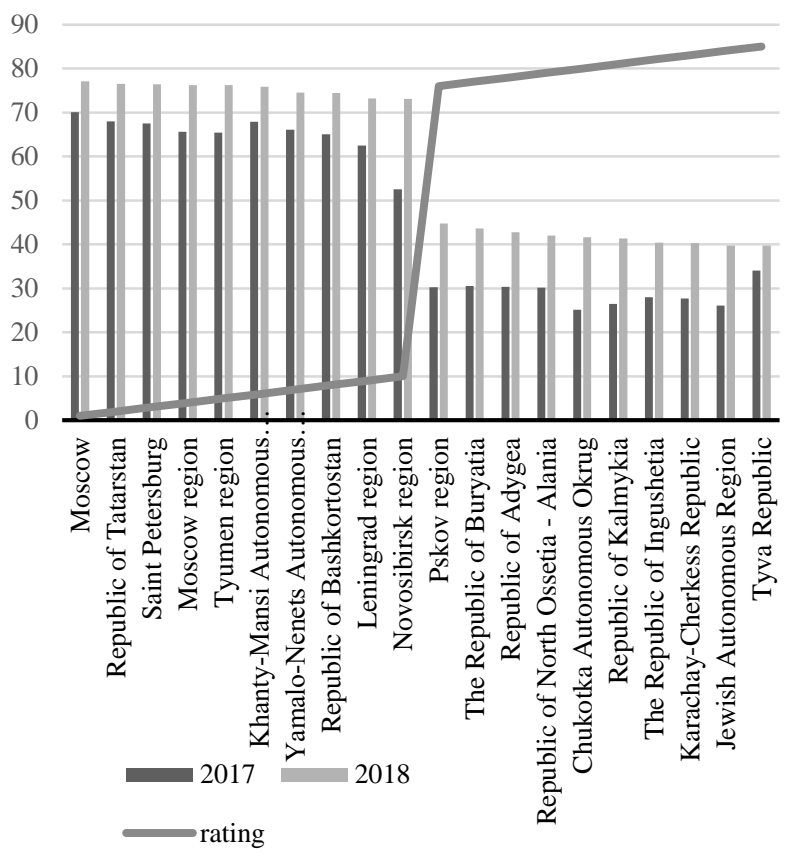

Fig. 2. Rating of Russian regions according to the Digital Russia index

The Digital Russia index of the first subject in the rating (Moscow) is almost twice as high as the last subject of the rating (the Republic of Tyva), and, despite the positive dynamics of the index growth, the unevenness of the digitalization process of the constituent entities of the Russian Federation is evident. At the same time, information inequality is growing both at the level of national economies and at the global level between developed and developing countries (see fig. 2 [21]).

The development of ICT expands the boundaries of the national information space, which actively interacts with the information spaces of other countries, and contributes to the formation of a global information space.

In 1995, Russia developed the Concept for the Formation and Development of the Unified Information Space of Russia (UISR) and the corresponding state information resources. The UISR in the Concept is interpreted as "a set of databases and data banks, technologies for their maintenance and use, information and telecommunication systems and networks operating on the basis of interrelated principles and according to general rules and standards providing information interaction between organizations and citizens, meeting their needs for information services" [22]. On the basis of this 
document, in 1998 the Concept of State Information Policy was developed and approved. A number of state programs have been adopted, for example, the national program "Digital Economy of the Russian Federation", the implementation of which contributes to the development of information technology infrastructure and the formation of a single national information space. The program assumes an increase in domestic investment for the development of the digital economy from $1.7 \%$ of GDP in 2018 to $5.1 \%$ of GDP by 2024 . The task is set to provide $100 \%$ of socially significant infrastructure and $97 \%$ of households with the opportunity to connect to broadband access to the Internet $[23,24]$.

At the moment, the National Technological Initiative "Neuronet" has been adopted and is being implemented to create an environment for information exchange of a new generation, which is a new stage in the development of the information space. The project involves the direct integration of a person into the information space through the fusion of the human brain and computing devices and the development of neural technologies [25].

\section{CONCLUSION}

The formation of the information economy, the growth of digitalization in all spheres of society are a strategic priority of the Russian leadership. Informatization processes contribute to the transformation of the socio-economic system and contribute to its transition to a new stage of development - the information economy and information society [26]. The development of the information society is associated with the formation of a single national information space of the country, which, in the course of its development, interacts with the national information spaces of other countries and leads to the formation of a global information society and a global information space. The concept of an information space is inextricably linked with the concept of an information society $[27,28]$. Today, there is no single, generally accepted concept of the information society. According to the adopted Strategy for the Development of the Information Society in the Russian Federation for 2017-2030, the information society is interpreted as "a society in which information and the level of its application and accessibility radically affect the economic and sociocultural living conditions of citizens" [29] The implementation of the goal of this Strategy involves the achievement of an appropriate level of informatization and development of the national information space to ensure economic growth and sociopolitical stability. The formation of the information society presupposes the implementation of interaction between subjects in the information space environment through ICT, ensuring the quality and availability of information services for all consumers, preventing information monopoly and information isolation.

\section{Acknowledgments}

The article was prepared with the grant support of the Russian Foundation for Basic Research, project No. 19-01000318.

\section{References}

[1] Digital 2020: global digital overview. Retrieved from https://datareportal.com/reports/digital-2020-global-digital-overview

[2] UNCTAD Report "Digital Economy 2019: Value Creation And Capture: Implications for Developing Countries". Retrieved from https://unctad.org/system/files/official-document/der2019_en.pdf

[3] D. Bell, New technocratic wave in the West, Chapter in the book Social framework of the information society, Moscow: Progress, 1986.

[4] I.A. Lazarev, G.S. Khizha, and K.I. Lazarev, New information economy and network development mechanisms, Moscow: Dashkov and $\mathrm{K}, 2010$

[5] S.A. Dyatlov, O.S. Lobanov, and T.A. Selishcheva, "Information space convergence as a new stage of e-governance development in Eurasian economic space", in Proceedings of Internationsl Conference on Electronic Governance and Open Society: Challenges in Eurasia, 2017, pp. 99-106. DOI: http://doi.org/10.1145/3129757.3129775

[6] S.A. Dementyev, "Transdisciplinary analysis of the information space of modern society", Humanities, socio-economic and social sciences, 2017, vol. 8-9, pp. 35-39.

[7] T.A. Selishcheva, "Problems of Informational Inequality of the Russian Economic Space", VestnikSPbGEU, 2014, vol. 3(70), pp. 413. (In Russ.).

[8] I.A. Dobrovolskaya, "The concept of "information space": different approaches to its study and features", Bulletin of RUDN, 2014, vol. 4, pp. 140-147.

[9] V.Y. Tsvetkov, "Information space as a resource of knowledge", International Journal of Applied and Fundamental Research, 2016, vol. 3-2, pp. 207-212.

[10] M.V. Katkova "The concept of "information space" in modern social philosophy", Izvestia of the Saratov University. New series. Series: Philosophy. Psychology. Pedagogy, 2008, vol. 2, pp. 23-26. (In Russ.)

[11] S.A. Dyatlov, O.S. Lobanov, and W.V. Zhou, "The management of regional information space in the conditions of digital economy", Regional Economics, 2018, vol. 14(4), pp. 1194-1206.

[12] Universal digital inclusion. Retrieved from https://www.itu.int/ru/mediacentre/backgrounders/Pages/digitalinclusion-of-all.aspx

[13] Ministry of Digital Development, Communications and Mass Media of the Russian Federation. Information about broadband subscribers (statistical data). (In Russ.). Retrieved from https://digital.gov.ru/opendata/7710474375-abonentishpd/table

[14] Internet 2020 in Russia and the world: statistics and trends. (In Russ.) Retrieved from https://zen.yandex.ru/media/id/5b3b4d8b04251900aa532351/internet2020-v-rossii-i-mire-statistika-i-trendy-5e5ca553227f403871e7e957

[15] T.V. Mirolyubova, T.V. Karlina, and R.S. Nikolaev, "Digital economy: problems of identification and measurement in the regional economy", Economy of the region, 2020, vol.16(2), pp. 377-390.

[16] A.G. Granberg, Fundamentals of Regional Economy, Moscow: GU HSE, 2003

[17] A. Volkova, V. Plotnikov, Yu. Nikitin, V. Serba, and G. Detkov, "Digital economy development in Russia: prospects and problems", in Proceedings of 33rd International Business Information Management Association Conference, 2019, pp. 8220-8232.

[18] A.A. Volkova, V.A. Plotnikov, and Y.A. Nikitin, "Digital technologies of management in a globalized economy", in Proceedings of Globalization and its socio-economic onsequences, 2018, pp. 23922398.

[19] Ministry of Digital Development, Communications and Mass Media of the Russian Federation, 2019. (In Russ.). Retrieved from https://digital.gov.ru/ru/events/38782

[20] Federal State Statistics Service. Regions of Russia. Socio-economic indicators-2018. (In Russ.). Retrieved from http://www.gks.ru/bgd/regl/b18_14p/Main.htm

[21] Moscow School of Management SKOLKOVO. Index "Digital Russia”, 2019. (In Russ.). Retrieved from https://finance.skolkovo.ru/ru/sfice/research-reports/1779-2019-04-22

[22] Consultant Plus. The concept of formation and development of a single information space of Russia and the corresponding state information resources, 1995. (In Russ.). Retrieved from http://www.consultant.ru/cons/cgi/online.cgi?req=doc\&base=EXP\&n $=240699 \# 08996849197310592$

[23] The Passport of The national program "Digital Economy of the Russian Federation”, 2018. (In Russ.). Retrieved from 
http://docs.cntd.ru/document/552449906

[24] D.Iu. Miropolskiy, T.A. Selishcheva, S.A. Diatlov, I.B. Lomakina, and E.A. Borkova, "Regional supply chain structure and centralization of the economy of Russia", International Journal of Supply Chain Management, 2018, vol. 6(7), pp. 684-692. Retrieved from http://ojs.excelingtech.co.uk/index.php/IJSCM/article/view/2484

[25] About Neuronet. (In Russ.). Retrieved from http://rusneuro.net/chtotakoe-nejronet

[26] Zh.A. Ermakova, and I.N. Korabeynikov, "Formation of industrial relations inconditions of the formation of the digital economy in the
Russian Federation", Economy of the region, 2019, vol. 15(4), pp. 1199-1210.

[27] P.A. Minakir, "Russian economic space. Strategic dead ends", Economy of the region, 2019, vol. 15(4), pp. 967-980.

[28] E.V. Popov, and K.A. Semyachkov, "Problems of economic security of digital society in the context of globalization", Economy of the region, 2018, vol. 14(4), pp. 1088-1101.

[29] The Strategy for the Development of the Information Society in the Russian Federation for 2017-2030: Decree of the President of the Russian Federation, 2017. (In Russ.). Retrieved from http://docs.cntd.ru/document/420397755 